\title{
THE EFFECT OF PRODUCT FASCINATION, SERVICE FASCINATION, AND COMPETITIVE POWER OF TARIFF ON CUSTOMER SATISFACTION AND IMPACT ON TRANSACTION DECISIONS (Study on Agent BRILink BRI Branch of Pati)
}

\author{
Rizal Mahdi Kurniawan ${ }^{1}$ \\ Harry Soesanto ${ }^{2}$ \\ J. Sugiarto ${ }^{3}$ \\ 1,2,3 Master of Management, Faculty of Economics and Business, Diponegoro \\ University
}

\begin{abstract}
Bank Rakyat Indonesia (BRI) innovates to launch BRILink Agent services as a collaborative partner between BRI Bank and its customers. The problem in this research is how to improve customer satisfaction which will influence the decisions of transactions at BRILink BRI Branch of Pati. Data on observed variables were obtained through interviews with questionnaires to $110 \mathrm{BRI}$ Bank customers who transacted at BRILink Branch of Pati and tested using AMOS statistic software. The result of SEM analysis confirm the criteria of Goodness of fit that is Chi-Square is 154.616 with probability equal to 0.277; CMIN/DF (1.066); GFI (0.873); AGFI (0.833); TLI (0.991); CFI (0.992); and RMSEA (0.025). The result of hypothesis testing is: transaction decisions are statistically proven to be affected by customer satisfaction, customer satisfaction is statistically proven to be affected by service attractiveness and tariff competitiveness, while the attractiveness of unpaid products has a significant effect.
\end{abstract}

Keywords: Product fascination, service fascination, competitive power of tariff, customer satisfaction, transaction decisions

\section{INTRODUCTION}

The current economic development is experiencing changes in the business world as well as the increasingly tight level of competition among business actors, it encourages the business actors to innovate in determining the strategies that are appropriate with the marketing of these products. The company always strives to improve its competitiveness by seeking new sources of technology and good skills in shaping new corporate structures (Prahalad and Hamel, 1990). The era of globalization today, the competition between business in both the domestic market 
and the increasingly tight international market. One way to survive in this era of globalization is to increase the power and quality of sustainable services, this can be done by making product innovation or by effectiveness and efficiency in internal production. For efficiency and effectiveness in the production process that already run and can also be done on new products or innovation products that will be produced.

Various efforts made by banking companies such as BRI Bank continues to improve the innovation of the banking sector to be able to face a very tight competition with other banking firms. Sukapurnama and Kusumastuti (2013) explained that banks in Indonesia are still placing two strategies in business development: opening new offices and developing services through e-banking to improve the effectiveness and efficiency of banking operational costs. The development of information technology, telecommunication, and internet causes business actors to compete to make online or digital based business applications. The existing banking industry sector in Indonesia has utilized technology in a maximal way to meet the interaction needs of the company with its clients. BRILink becomes the latest innovation product issued by BRI Bank in meeting the needs of its customers and improving the quality of modern banking services. The BRILink product is the result of branchless banking implementation. This product is operated by an agency system or a third party involving between the bank and the customer. The existence of this product can provide ease in transactions for a customer in real time online. BRILink provides benefits for agents in the form of fee sharing. Here are the services of BRILink products including Mini ATM BRI, BRIZZI, BRIVA, and T-Bank (electronic money) where the account number is based on the mobile phone number.

BRI Branch of Pati is a part of Semarang Regional Office, BRI Kanca Pati has 1 main branch office, 2 Sub-Branch Offices (KCP), 2 Cash Offices (KK), 41 Office Units, and $18 \mathrm{BRI}$ Terraces scattered in Pati area. BRI Pati shows its commitment to fulfilling the quality of services provided to the community in the development of unit offices that will facilitate the community in banking transactions through BRI Bank. BRI Bank branch of Pati also continues to develop in the increase of transaction, Fee-Based Income (FBI), and profit through Agent BRILink which has been formed since 2014. The growth of BRILink agent transactions that is still below the target figure indicates that there is an unwillingness of customers to make transactions. This is a problem in this study, based on the formulation of the problem, then this research needs to formulate the existing problems that are: "how to improve the decisions of customer transactions BRI Bank Kanca Pati in Agent BRILink". From the description of the above problems, so developed some questions in this study are: (1) Will the fascination with BRILink's products improve 
BRI bank customer satisfaction?; (2) Will the fascination of BRILink agency services improve BRI bank customer satisfaction?; (3) Can the competitiveness of BRILink agent rates increase BRI bank customer satisfaction?

\section{LITERATURE REVIEW}

\section{TAM (Technology Acceptance Model)}

Competition banking industry increasingly stringent makes the company do technology development and innovation to improve customer satisfaction. TAM (Technology Acceptances Models) is a model of behavior that utilizes information technology and refers to its management information system (Munusamy et al., 2012). TAM aims to explain or estimate from the application of technology in an organization and the factors that influence it in the application of these technologies. There are two concepts proposed by Davis (1989) in Istiarni (2014) which are believed to be user acceptance of perceived ease of use and perceived usefulness. The expansion of the concept of TAM is expected to help predict the attitudes and acceptance of a person against the applied technology and can provide basic information to be used on the factors driving the individual's attitude (Devi, 2014). Goyal Shika et al. (2016) added that technological developments encourage banks to continue to innovate by making Electronic Banking (E-banking) easily accessible in the community, for example, Automated Teller Machine (ATM), Internet Banking, and Mobile Banking. This is to improve customer convenience, reduce operating costs, and maintain profitability.

\section{Transaction Decisions}

Consumers have a role to provide a decision in using products or services offered by marketers. Decision-making on consumer behavior in determining the purchase of a product or service there is something that underlies the consumer to do so. Where consumers who meet the needs by actualizing that there is in itself as well as a very strong motivation to achieve it is a purchase decisions (Archana and Khanna, 2012). Ismail and Osman (2012) added that motivation can give a strong force or motivation and motivation in a person to be able to perform an action in accordance with what they expect. Raida and Bouslama (2013) explain that a person's motivation or interest in using electronic banking as the right decisions to transact online. In generally there are 2 or more parties involved in a buying process to the purchase decisions of a consumer goods.

\section{Product Fascination}

The product fascination is an allure or magnet of a particular product that can affect consumers to have it. The product fascination is also interpreted as a very good 
quality of the product, so the quality of a product can affect consumers to have it. Methaq and Salam (2012) add that attraction is defined as consumer interest to buy the product. An option has dominated the other, then the goods or services in a product will be underestimated, so the consumer will determine or buy on the choice of one such product. Thus, fascinations indicate a very strong influence on a choice of product comparators and evaluate them separately by shifting from reference information to an option. Melodie and Kim (2012) added that the product fascination both goods and services can be seen from the form of goods itself which has an opportunity value for business actors to gain greater benefits.

\section{Service Fascination}

The service fascination is the level of service quality that the company provides to its customers. Service quality is the combined aggregate and service characteristics of marketing, design, manufacturing and maintenance activities through the use of products and services that will meet customer expectations (Armand, 1992 in Siagian, 2006). Parasuraman et al., (2012) explains that if the services that have been given to customers or consumers have been in line with expectations then the service quality can be satisfactory for customers or consumers. Basit et al., (2014) adds that if the quality of service provided and the quality of the products being sold very well will provide a positive level of influence on customer satisfaction. Service quality is an important and very complex element of consumer perception because it is intangible and its production and consumption runs simultaneously. Service quality can be determined after consumers evaluate whether or not satisfied service offered, then consumers give perceptions on the service quality.

\section{Tariff Competitiveness (Price)}

Price is a mix of direct revenue-generating for the company, but there are other marketing mixes that will result in cost. Cravens and Piercy (2003) argue that strategy in goods and services pricing has become the company's key to deregulation, low growth in the market, for the company to make an opportunity to gain control and exploit markets and increasingly competitive globally. Price is not the nominal form of an item, but rather the element of marketing such as the selling price of the prod, discount, and payment system (Abdul Muhmin, 2002). Price is the cost resulting from a purchase (Tse, 2001, in Chitty, 2007) that together with the service quality affecting the perception of customer value. It affects the amount to be purchased at the offered price (Monroe, 1990, in Chitty, 2007). The amount paid depends on the needs and services provided. Price is believed to have an impact on the perception of quality because high-quality products will provide good quality rather than low quality (Chitty, 2007). 


\section{Customer Satisfaction}

Customer satisfaction makes special attention or very important for all banking business actors engaged in the service sector. Customer satisfaction becomes the main concept or strategy for banking companies to be able to win the competition in service sector business world. Mowen and Minor (2001) stated that customer satisfaction is an attitude shown by customers or customers of goods or services they have consumed. Customers have a role in determining the level of satisfaction of a product or service provided by the company (Abdullah and Nento, 2014). According to Zeithaml and Bitner (2008) explained that customer satisfaction is part of the response or response from customers on products or services that have been accepted and evaluated and perceived a discrepancy between expectations and actual performance. Services that have been received by customers need to be evaluated by determining the level of service quality that the company provides in order to provide the level of product satisfaction for services that have been consumed. The customer will be able to feel if they have bought or used the product or service and realized whether the product or service has been used as expected or not.

\section{Hypothesis}

\section{The Effect of Product Fascination on Customer Satisfaction}

Mowen et al. (2002) explained that product fascination has a direct effect on the level of customer satisfaction. Increased ability on a product that can create a competitive advantage, so that customers more satisfied. Customers will move to a product or service that can understand and be able to complete the customer's demand and provide better service levels. Mulyono et al., (2007) states that the higher the level of product quality, the higher the level of customer satisfaction. Basith et al., (2014) adds that the product fascination has a significant effect on customer satisfaction.

H1: The product fascination has a positive effect on customer satisfaction

\section{The Effect of Service Fascination on Customer Satisfaction}

The service fascination indirectly illustrates the level of product quality and its reputation in enhancing customer satisfaction. In his study, Chesrek et al. (2015) revealed that customer satisfaction makes things very important for companies, especially services (banking). The quality of the company's services can also change the company's performance patterns to become better with increased customer satisfaction. Likumahua (2010) explains that the company's service quality provides to the customer has positive effect level on the customer satisfaction level. Murugiah and Akgam (2015) added the service quality and 
customer loyalty to provide has a significant level of positive effect on customer satisfaction as well as providing has a negative sign on the security and customer satisfaction level.

H2: Service fascination has a positive effect on customer satisfaction

\section{The Effect of Tariff Competitiveness on Customer Satisfaction}

Samaan (2015) said that the price or tariff is the amount of money or expenses incurred for a product or service we receive. Utami (2015) adds that if there is a correlation between price and loyalty towards the customer or consumer satisfaction level, the price is usually viewed by consumers as an indicator of the value that connects with the benefits that consumers have received or feel both in the product or service. Where the price set by the company is not in accordance with what is expected the customer will decrease the satisfaction of the goods or services, vice versa if in determining the price of a good or service that the company spend in accordance with the benefits or expectations of customers it can increase customer satisfaction.

H3: Tariff competitiveness has a positive effect on Customer Satisfaction

\section{The Effect of Customer Satisfaction on Transaction Decisions}

The customer satisfaction level is higher if the perceived benefits of customers greater than the level of income to get it, it will encourage to buy the product. Conversely, if the benefits that the customer or the customer receives is less than the price of the sacrifice then the customer refuses or switches to buy other similar products or services. The customer has a very important role in determining the measurement of the level of customer satisfaction with the products or services provided to the company (Abdullah and Nento, 2014). Customers will choose a bank that can provide satisfaction levels in terms of services or products offered in accordance with the expectations of the customer itself. Hidayat (2015) states that consumer satisfaction has a positive effect on purchasing decisions. The decisions in the purchase are influenced by the value of the product that has been evaluated. H4 : Customer satisfaction has positive effect on transaction decisions

\section{Theoretical Framework}

The theoretical framework explains how the effect of correlation between variables one towards other variables. In order to clarify the picture of the theoretical framework, it will be described in Figure 1. 
Figure 1

Theoretical Framework

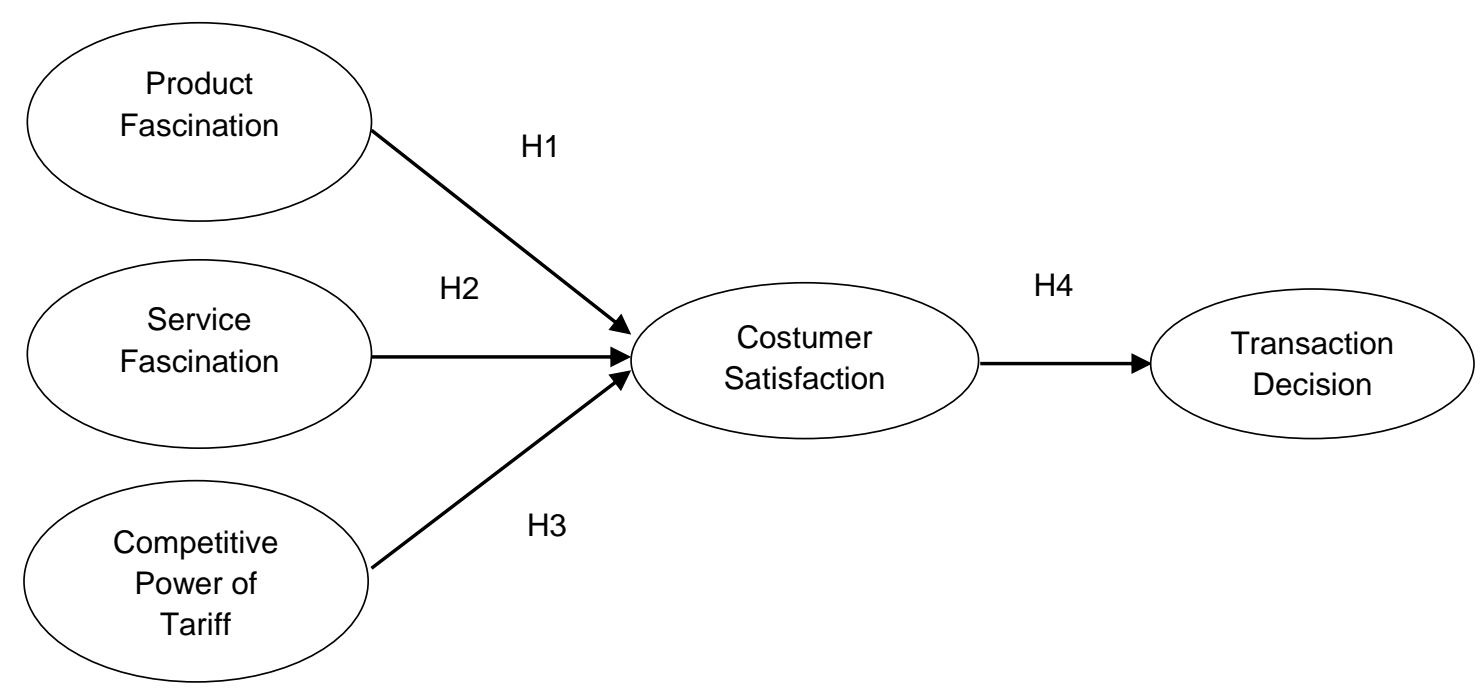

Sources: Boyd and Masson (1999), Garvin (1998), Ruyter et al (1996), Lupiyoadi and Hamdani (2006), Ferdinand (2002) Oliver (1993) Levesque and McDouglall (1996) (Pepadri, Sitinjak, in Wibowo and Karimah, 2012) Aaker in Astuti and Cahyadi (2007).

\section{RESEARCH METHOD}

Customers of BRI Bank of Pati become subject population in this research. Sampling is a nonprobability sampling approach. Samples are 110 respondent. This study research using SEM that requires sample at least 100 respondents. Primary data is data obtained factually or directly and this data is deliberately obtained exclusively to answer the research questions. Data collection technique using a closed questionnaire method with a Likert scale. Data analysis process using the validity and reliability test and SEM hypothesis.

\section{Figure 2}

\section{Path Diagram}

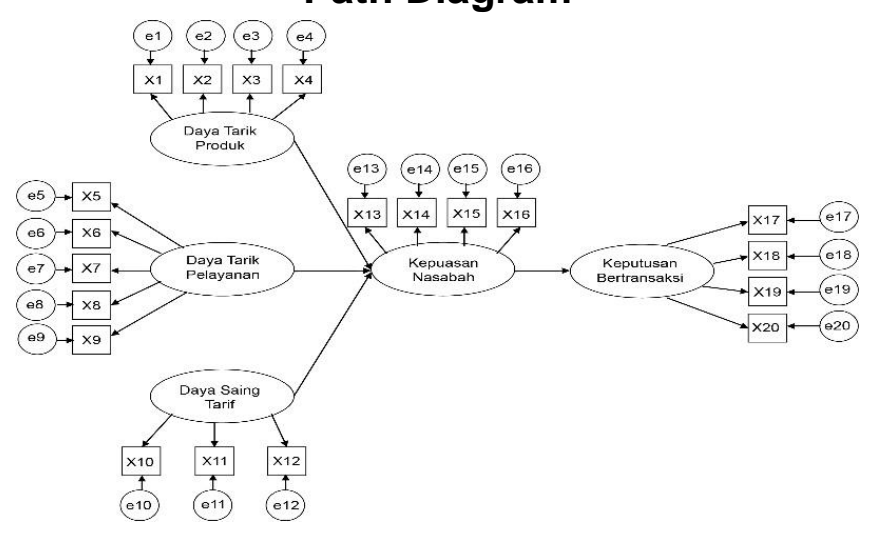


This research tool is SEM is used as an analytical tool. Ferdinand (2002) said that the reasons for analyzing research data using SEM are: (1) Indicates the dimensionalization unit of the indicator of dimension or collision or factor; (2) See the suitability and accuracy of a model based on the empiric data it has examined; (3) Testing of the suitability of the research model or the relationship of causality between factors that have been built or observed in the research model. According to Ferdinand (2002 revealed that there are 7 (seven) stages to be taken in the use of the SEM model. The SEM model itself consists of a Measurement Model and Structure Model.

\section{DATA ANALYSIS AND DISCUSSION Research Model Testing}

Research model testing looking at the suitability between the proposed model with shown from the results of the research model through the results of the goodness of fit on the research model. The model proposed in this study can be known from the causal relationship between product quality, service quality, tariff competitiveness, customer satisfaction, as well as on the transaction decisions, the results of the model research processing on figure 3.

Figure 3

\section{Research Model Testing Results}

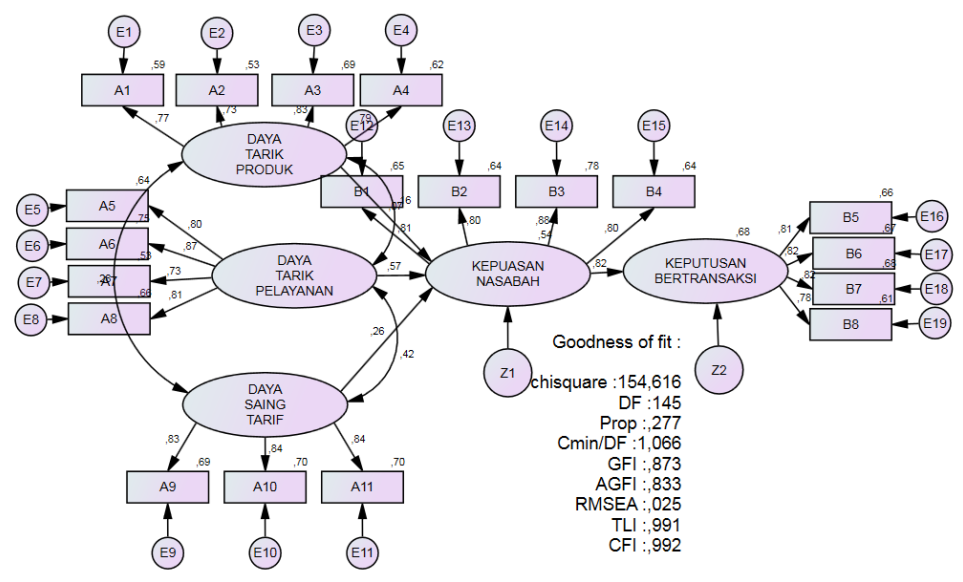

The goodness of fit testing to know between model accuracy towards research data. Determining whether or not on a research model is effected the index of the test results compared with the critical value. 
Table 1

The goodness of Fit Indexes for Full Model

\begin{tabular}{|c|c|c|c|}
\hline $\begin{array}{c}\text { Goodness of } \\
\text { fit index }\end{array}$ & Cut off value & Results & $\begin{array}{c}\text { Model } \\
\text { Evaluation }\end{array}$ \\
\hline $\begin{array}{c}\text { Chi-square } \\
\text { (df=145) }\end{array}$ & $<174,101$ & 154,616 & Good \\
\hline Probability & $\geq 0,05$ & 0,277 & Good \\
\hline CMIN/DF & $\leq 2,00$ & 1,066 & Good \\
\hline GFI & $\geq 0,90$ & 0,873 & Marginal \\
\hline AGFI & $\geq 0,90$ & 0,833 & Marginal \\
\hline TLI & $\geq 0,95$ & 0,991 & Good \\
\hline CFI & $\geq 0,95$ & 0,992 & Good \\
\hline RMSEA & $\leq 0,08$ & 0,025 & Good \\
\hline
\end{tabular}

Data processing results in the table above show that the evaluation of the overall model categorized well or fulfill the required criteria of the required assessment. Chi-square value's research model is considered good if the results of the calculated chi-square value show a smaller value than the chi-square table, it is clear that if there is no difference between population estimation and the sample in the tested study indicates the better the research model. Chi-square value on the data above the results of the research model is 154.616, where the critical value of chi-square table with DF $=145$ is 174.101 . From the results can be explained that the results of the model research showed that the value of calculated chi-square is smaller than the value of chi-square table, this explains that this research model is no difference in the population that is estimated and considered good or accepted. The goodness of fit of other indexes such as probability, RMSEA, CMIN, TLI, CFI is still within the required range of values so well considered, and at the GFI and AGFI index values in the table above shows the model evaluation on the marginal criteria meaning they are still in the range the required or expected value, and overall the model in this study is good.

\section{Direct and Indirect Effect Analysis}

The purpose of effect analysis between directly or indirectly variables is to know the largest effect so it will be easier to do future strategy election. In the table 2 presented about the results of the direct and indirect effect. The effect analysis is used to analyze the strength of effect between constructs, either direct or indirect effect. The coefficient of all coefficient lines with one end dart is called direct effect, whereas the effect that arises through a variable is an indirect effect. The effects of various correlation are called total effects (Ferdinand 2006). Based on data processing results using SEM in full model research shows direct value and indirect 
effect of product fascination, service fascination, tariff competitiveness, customer satisfaction, and transaction decisions variables, shown in table 2.

\section{Table 2}

Direct and Indirect Effect Analysis

\begin{tabular}{|l|c|c|}
\hline & $\begin{array}{c}\text { Direct } \\
\text { Effect }\end{array}$ & $\begin{array}{c}\text { Indirect } \\
\text { Effect }\end{array}$ \\
\hline Product Fascination on Customer Satisfaction $(\mathrm{X} 1-\mathrm{Y} 1)$ & 0,118 & \\
\hline Service Fascination on Customer Satisfaction $(\mathrm{X} 2-\mathrm{Y} 1)$ & 0,618 & \\
\hline Tariff Competitiveness on Customer Satisfaction $(\mathrm{X} 3-\mathrm{Y} 1)$ & 0,276 & \\
\hline Customer Satisfaction on Transaction Decisions $(\mathrm{Y} 1-\mathrm{Y} 2)$ & 0,804 & \\
\hline Product Fascination on Transaction Decisions $(\mathrm{X} 1-\mathrm{Y} 2)$ & & 0,094 \\
\hline Service Fascination on Transaction Decisions $(\mathrm{X} 2-\mathrm{Y} 2)$ & & 0,496 \\
\hline Tariff Competitiveness on Transaction Decisions $(\mathrm{X} 3-\mathrm{Y} 2)$ & & 0,222 \\
\hline
\end{tabular}

The table 2 can be seen that direct effect of product fascination on customer satisfaction is 0.118 , the direct effect of service fascination on customer satisfaction 0.618 , the direct effect of tariff competitiveness on customer satisfaction 0.276 , and direct effect of customer satisfaction on transaction decisions 0.804 . The indirect effect of products fascination on transaction decisions 0.094 , the indirect effect of service fascination on transaction decisions 0.496 , the indirect effect of tariff competitiveness on transaction decisions 0.222 .

\section{Discussions}

Hypotheses result discussion from 1 to hypothesis 4 can be seen in table 3 .

\section{Table 3}

Hypothesis Results

\begin{tabular}{|l|c|}
\hline \multicolumn{1}{|c|}{ Hypothesis } & Testing Result \\
\hline H1: The Higher Product Fascination The Higher & Rejected \\
BRILink Customer Satisfaction Level & Accepted \\
\hline H2: The Higher Service Fascination The Higher & \\
BRILink Customer Satisfaction & Accepted \\
\hline $\begin{array}{l}\text { H3: The Higher Tariff Competitiveness The Higher } \\
\text { BRILink Customer Satisfaction Level }\end{array}$ & Accepted \\
\hline H4: The Higher Customer Satisfaction The Higher & \\
Transaction Decisions & \\
\hline
\end{tabular}

\section{[H1] Hypothesis Results Discussion}

Data processing result hence obtained the relation between a variable that is product fascination on customer satisfaction as hypothesis I do not fulfill the requirement for hypothesis I. Analysis result show $C R$ value is 0.782 under 1.96 and probability value $(P)$ is $0 ., 434$ above 0,05 so that it cannot qualify from $\mathrm{H} 1$ accepted. The dimensions of the shaper of product fascination have no effect on customer 
satisfaction. This indicates that BRI's bank product fascination does not affect BRILink customer satisfaction level, from open questions that have been given to the respondents this is affected by several things such as consumers who tend not to know about the agency BRILink itself, consumers still cannot distinguish between agency BRILink, ATM, and office units. Consumers are not fully aware of BRILink agent products and services.

\section{[H2] Hypothesis Results Discussion}

Data processing result is obtained for the correlation between service fascination variable the higher the BRILink customer satisfaction as hypothesis 2 which fulfill the requirement of acceptance of hypothesis 2. CR value analysis results in 5.304 above 1.96 and probability value $(p)$ is $<0.05$ below 0.05 to qualify from the acceptance of $\mathrm{H} 2$. The dimension of service fascination affects BRILink on customer satisfaction. This shows that good service fascination can increase customer satisfaction BRILink. There are other factors beyond Pulling Services that can increase customer satisfaction BRILink including agents provide a clear explanation of BRI customers who make transactions at BRILink agents so that customers are satisfied and will re-transact the agent because it is easier, safer and faster accordingly with what the customer wants. Service quality is known to have a major effect on customer satisfaction levels, this is because customers want to be treated well to feel valued, but if customers are treated uncomfortably, they are likely to put on disappointment and share their experiences with others.

\section{[H3] Hypothesis Results Discussion}

There is a correlation between variables based on the results of the data processing that the tariffs competitiveness variable the higher the level of customer satisfaction BRILink as hypothesis 3 has been eligible for acceptance of hypothesis 3. CR value shows 2.684 above 1.96 and the probability value (p) 0.007 below 0.05 to qualify for H3 acceptance. The dimension of tariff competitiveness effect on BRILink customer satisfaction level, it shows that the benefits that have been received by the customer in accordance with what has been expected. Tariffs charged by BRI customers who perform at BRILink agents make an impact on the satisfaction level of the customers themselves, as each agent is entitled to determine the number of administrative fees charged by BRI bank customers who will perform the transaction at the BRILink agency.

\section{[H4] Hypothesis Results Discussion}

Correlation between variables from the result of data processing shows that customer satisfaction variable on transaction decisions at hypothesis 4 fulfill the 
requirement from acceptance hypothesis 4. CR value show 7.703 above 1.96 and probability value $(p)$ is $<0.05$ so fulfill the requirement of $\mathrm{H} 4$ acceptance. The dimension of customer satisfaction effect on transactions decisions. This shows that the benefits obtained from Bank BRI could increase the number of transactions. The level of satisfaction that the customer receives will provide a positive decision on BRI customers to conduct transactions at BRILink agents with consideration of affordable services and tariffs as well as the speed and security of BRILink agents offer. In a study conducted at BRILink agents, the researchers conducted open interviews of BRI bank customer respondents who transacted at BRILink agents around their home environment, they were generally pleased with the presence of BRILink agents in their neighborhood, as banking transactions could be done with faster, closer, safer, and easier so they feel satisfied and can trade on BRILink agents so that an increasing number of transactions can be achieved.

\section{CONCLUSIONS AND SUGGESTIONS}

\section{Conclusions}

This research purpose to analyze the effect of product fascination, service fascination, tariff competitiveness on transaction decisions through customer satisfaction level. Respondent's data are 110 respondents who have been asked to fill out questionnaires in which there are questions that are used to measure the extent of the effect between product fascination, service fascination, and tariff competitiveness and customer satisfaction on transaction decisions. The results were four hypotheses, 3 of which were accepted and (proven to have a positive effect) while the other 1 was rejected or not proven to have a positive effect. The greatest effect is the effect of customer satisfaction on transaction decisions. This study found the results that consumers will put high confidence in the company if they get treatment and good service, this good service includes the agent's own friendliness. This research purpose to answer the problem of existing research is how to improve transaction decisions in BRILink Agent. The results are further used to help draw conclusions and produce three basic processes in improving transaction decisions, such as: by increasing products fascination, service fascination, and tariff competitiveness to obtain customer satisfaction, then customer satisfaction has a great effect on consumer attitudes when will do the transaction in BRILink agent.

\section{Research Limitations}

This research there are still limitations and weaknesses, where the existence of these limitations and weaknesses can be used as a reference for future research. Here are the limitations: (1) Based on the results of this research which only service fascination and tariff competitiveness on customer satisfaction, while products fascination did not affect customer satisfaction; and (2) The breadth of territory and 
the characteristics of the community, as well as the educational background of the respondents, are also something to consider.

\section{Suggestions}

This research there are still limitations which can be used as the basis and evaluation in subsequent research. Here are suggestions for further research: (1) This research there are still variables that need to be added to replace product fascination variable; (2) Scope of data research more widely to obtain broader data in this study, for example, the level of the Regional Office of Semarang representing from various branches then future research will be more detailed and valid in conducting research on the factors that effects transaction decisions in BRILink agents; and (3) There are several variables that can be developed or researched in subsequent research including Promotion or advertising, Word of Mouth (WOM), and Motivation.

\section{REFERENCES}

Abdul, Muhmin. 2002. "Effects Of Suppliers Marketing Program Variables On Industrial Buyer's Relationship Satisfaction and Commitment". Journal of Business and Industrial Marketing. Vol. 17. No.7. P.637-651.

Abdullah AH, Nento S. 2014. "Pengaruh Kualitas Layanan dan Kepuasan Pelanggan terhadap Loyalitas Pelanggan Perpustakaan". Jurnal Manajemen Pendidikan Islam. Vol 2. No 2. P.161-171.

Aryani D dan Rosinta F. 2010. "Pengaruh Kualitas Layanan terhadap Kepuasan Pelanggan dalam Membentuk Loyalitas Pelanggan". Jurnal IImu Adminitrasi dan Organisasi. Mei-Agustus. Vol.17 No. 2. P 114-126.

Basith A, Kumadji S, Hidayat K. 2014. "Pengaruh Kualitas Produk dan Kualitas Pelayanan terhadap Kepuasan Pelanggan dan Loyalitas Pelanggan (Survei Pada Pelanggan De'pans Pancake And Waffle Di Kota Malang". Jurnal Administrasi Bisnis (JAB). Vol 11. No 1. P 1-8.

Cheserek LK, Kimwolo AK, and Felishana C. 2015. "Effect Of Quality Financial Services On Customer Satisfaction By Commercial Banks In Kenya". International Journal Of Humanities and Social Science. Vol 5, No 7. P 102-112.

Chitty, Bil. 2007 "An Application Of The Ecsi Model As A Predictor Of Satisfaction And Loyalty For Backpacker Hostels". Marketing Intelligence \& Planning. Vol 25 No 6. P 563-580.

Cravens, David W, and Nigel FP. 2003. Strategic Marketing Seventh Edition. New York: Mc Graw-Hill.

Ferdinand, AT, 2005, "Structural Equation Modeling dalam Penelitian Manajemen". BP Undip. Semarang.

Ferdinand, Augusty. 2006. "Metode Penelitian Manajemen". Badan Penerbit Universitas Diponegoro. Semarang.

Goyal Shika, Chawla Diksha, Bhatia Ambika. 2016. "Innovation: Key To Improve Business Growth Of Banking Industry" International Journal Of Advances In Engineering \& Technology. Vol. 9. Issue 3. P 331-346.

Hidayat R. 2015. "Pengaruh Kepuasan Konsumen Terhadap Keputusan Pembelian Lampu Philips (Studi Kasus Pada Mahasiswa Telkom University)". Ecodemica. Vol 3. No 1. P $305-310$. 
Kurniawati D, Suharyono, Kusumawati A. 2014. "Pengaruh Citra Merek dan Kualitas Produk terhadap Kepuasan dan Loyalitas Pelanggan (Studi pada Pelanggan KFC Cabang Kawi Malang)". Jurnal Administrasi Bisnis (JAB). Vol 14. No 2. P 1-9.

Likumahua, D. 2010. "Faktor Kualitas Layanan serta Pengaruhnya terhadap Kepuasan dan Loyalitas Nasabah Perbankan di Ambon". Vol 4. No 2.

Melodie, Ray Davis-Bundrage, dan So Young Kim. 2012. "Predicting Purchase Of Eco Beauty Products: A Qualitative Meta-Analysis," Atlantic Marketing Association.

Mowen, John C, and Minor Michel. 2002. Perilaku Konsumen. Jilid 1 Edisi 5. Erlangga Jakarta.

Mulyono BH, Nugraheni R, Kamal M. 2007. "Analisis Pengaruh Kualitas Produk dan Kualitas Layanan terhadap Kepuasan Konsumen (Studi Kasus Pada Perumahan Puri Mediterania Semarang)". Jurnal Studi Manajemen dan Organisasi. Vol 4. No 2. P 97.

Munusamy J, Sanmugam A, and Shankar C. 2012. "A Study Of User Of Internet Banking On Malaysia," International Journal Of Innovation, Management, and Technology. P 398-404.

Murugiah L, Akgam HA. 2015. "Study Of Customer Satisfaction In The Banking Sector In Libya". Journal Of Economics, Business, And Management. Vol 3. No 7. P 674-677.

Parasuraman, A, VA Zeithaml \& LL Berry. 1988. "A-Multiple Item Skill For Measuring Consumers Perception Of Service Quality". Journal Of Retailing. Vol. 64. P 12-40.

Parasuraman. A, Zeithaml, VA and Berry, LL. 1994. "Reassessment Of Expectations As A Comparison Standar In Measuring Service Quality: Implication For Further Research". Journal Of Marketing. Vol. 58. P 111-124.

Quyet TY, Nguyen QV, Taikoo C. 2015. "Service Quality Effects On Customer Satisfaction In Banking Industry", Science and Technology. Vol 8. No 8. P 199-206.

Raje, Archana., dan Vandana, Tandon Khanna. 2012. Impact of E-Service Quality on Consumer Purchase Behaviour in an On-line Shopping. IJCSMS International Journal of Computer Science and Management Studies.12 (02), P 1-5.

Sakapurnama Eko dan Kusumastuti Retno. 2013. "The Development Of Online Banking System In Indonesia, Implication In Human Resources Management Strategy" Advances In Management \& Applied Economics, Vol 3. No 2. P 123-134.

Sallam, Methaq Ahmed Abdulmajid. 2011. "The Impact Of Source Credibility On Saudi Consumer's Attitude Toward Print Advertisement: The Moderating Role Of Brand Familiarity". International Journal of Marketing Studies. Vol 3. No 4. P 63-77.

Samaan Al-Msallam. 2015. "Customer Satisfaction And Brand Loyalty In The Hotel Industry". European Scientific Journal. Vol.1. 232-51p.

Siagian, MY dan Handayani P. 2006. "Pengaruh Motivasi dan Visi Kerja Karyawan Serta Kegagalan Kualitas Pelayanan Di Masa Lalu Terhadap Peningkatan Kualitas Pelayanan Pada Fakultas Ekonomi Universitas Trisakti". Media Riset Bisnis dan Manajemen. Vol 6. No 2.

Utami, ND. 2015. "Pengaruh Kualitas Produk, Pelayanan, Harga, dan Lokasi terhadap Loyalitas dengan Kepuasan Sebagai Variabel Intervening", Jurnal IImu dan Riset Manajemen. Vol 4. No 5. P 1-20.

Zeithaml, Valarie. A. 1998. "Consumer Perception Of Price, Quality, and Value: A MeansEnd Model and Synthesis Ofevidence". Journal Of Marketing. Vol 52. No 2. P 22. 